\title{
PHYSICAL ATTRIBUTES OF SOIL AFTER SWINE WASTEWATER APPLICATION AS COVER FERTILIZER ON MAIZE CROP AND BLACK OATS SEQUENCE ${ }^{1}$
}

\author{
FÁBIO PALCZEWSKI PACHECO ${ }^{2}$, LÚCIA HELENA PEREIRA NÓBREGA ${ }^{3}$, MICHELLE TONINI $^{3}$, ARIANE \\ SPIASSI ${ }^{4}$, DANIELLE MEDINA ROSA ${ }^{5}$, CLÁUDIA TATIANA DE ARAÚJO DA CRUZ-SILVA ${ }^{5}$
}

\begin{abstract}
The rate of swine wastewater application (SW) in agricultural production could result in the replacement of chemical fertilizers. However, SW destroys soil physical properties by decreasing pore bulk, which negatively affects both crop yield and development. In this context, this study aimed at monitoring the influence of swine wastewater as a cover fertilizer in maize and black oats in sequence on soil physical properties. Five application rates $\left(0,100,200,300\right.$ and $537 \mathrm{~m}^{3}$ ha ${ }^{-1}$ equivalent to $0,11.2,22.3,33.5$ and $60 \mathrm{~kg} \mathrm{ha}^{-1} \mathrm{~N}$, respectively, based on the average nitrogen concentration in SW) were tested with four replications each. In the studied area, soil porosity, density, and water content, before maize sowing and at the end of the cycles of maize and black oats, were determined by the volumetric ring method. Data were submitted for regression analyses. There was a reduction in the macroporosity and total porosity of the soil when the SW application rate, before maize cultivation, was higher. The introduction of black oats helped to improve the physical quality of the soil and reduced the compaction of the surface layer from 0 to $15 \mathrm{~cm}$ and 100 to $300 \mathrm{~m}^{3} \mathrm{ha}^{-1} \mathrm{SW}$ rates.
\end{abstract}

Keywords: Swine manure. Plant nutrition. Water reuse. Avena strigosa Schreb. Zea mays.

\section{ATRIBUTOS FÍSICOS DO SOLO APÓS APLICAÇÃO DE ÁGUA RESIDUÁRIA DE SUINOCULTURA APLICADA EM COBERTURA NA CULTURA DO MILHO E CULTIVO SEQUENCIAL DE AVEIA PRETA}

\begin{abstract}
RESUMO - As taxas de aplicação de águas residuárias de suinocultura (ARS) utilizadas na produção agrícola podem substituir a adubação convencional, mas também podem prejudicar atributos físicos do solo pela diminuição do volume de poros, e consequentemente o rendimento e desenvolvimento das culturas. Neste contexto, o objetivo deste trabalho foi monitorar a influência do uso da água residuária de suinocultura como adubação de cobertura na cultura do milho e aveia preta em sequência sobre atributos físicos do solo. Cinco taxas de aplicação $\left(0 ; 100 ; 200 ; 300\right.$ e $537 \mathrm{~m}^{3} \mathrm{ha}^{-1}$ sendo equivalentes a $0 ; 11,2 ; 22,3 ; 33,5$ e $60 \mathrm{~kg} \mathrm{ha}^{-1}$ de N , respectivamente, baseado na concentração média de $\mathrm{N}$ na ARS) foram testadas, com quatro repetições cada. No solo, foram determinados porosidade do solo, densidade, teor de água antes da semeadura do milho e ao final dos ciclos do milho e aveia preta, pelo método do anel volumétrico. Os dados foram submetidos a análises de regressão. Houve redução da macroporosidade e porosidade total do solo quanto maior a taxa de aplicação na cultura do milho. A introdução da aveia preta contribuiu para melhorar a qualidade física do solo e reduziu a compactação na camada superficial de $0-15 \mathrm{~cm}$, para taxas de ARS de100 a $300 \mathrm{~m}^{3} \mathrm{ha}^{-1}$.
\end{abstract}

Palavras-chave: Dejetos suínos. Nutrição vegetal. Reuso de água. Avena strigosa Schreb. Zea mays.

\footnotetext{
${ }^{*}$ Corresponding author

${ }^{1}$ Received for publication in 11/11/2014; accepted in 10/19/2016

Paper extracted from the Master's dissertation of the first author.

${ }^{2}$ Department of Biological and Environmental Sciences, Universidade Tecnológica Federal do Paraná, Medianeira, PR, Brazil; fabiop.pacheco@gmail.com.

${ }^{3}$ Agricultural Engineering Post-graduation Program, Universidade Estadual do Oeste do Paraná, PR, Brazil; lucia.nobrega@unioeste.br, mi_tonini@yahoo.com.br.

${ }^{4}$ Universidade Estadual do Oeste do Paraná, Francisco Beltrão, PR, Brazil; arispiassi@hotmail.com.

${ }^{5}$ Universidade Estadual do Oeste do Paraná, Cascavel, PR, Brazil; danimrosa@yahoo.com.br, claudia_petsmart@hotmail.com.
} 


\section{INTRODUCTION}

The monitoring of soil quality using physical indicators is important for maintaining and evaluating its sustainability. Several soil properties are studied to evaluate soil quality in relation to water erosion namely organic matter content, soil bulk, macro, micro and total porosity, mechanical resistance to penetration and soil permeability to water in soil management systems (SILVA et al., 2011).

The incorrect application of swine manure can cause problems in the soil such as macropores clogging, which causes surface sealing, reduction in water infiltration, and gas exchanges between the atmosphere and the soil. It also offers the risk of salinization, soil and plant pollution with heavy metals, man and animal contaminated by pathogens from animal wastes (ZAMANI et al., 2016).

Soil bulk density is affected by crops that change the soil structure and pores arrangement, which influence water retention by the soil, aeration, water availability to plants and soil resistance to penetration (RIENZI et al., 2016).

According to Reis, Fadigas and Carvalho (2005), water reuse has significantly contributed to agricultural sustainability and it has been used as an alternative control of pollution sources in springs, as well as for nutrients recycling and increasing agricultural production.

Soil porosity is important for achieving the proper circulation of water, nutrients and air. Thus, its study can determine the physic-hydric behavior of soil characteristics according to the distribution of different pore diameters (VARALLO et al., 2010).

Pores attribution can be observed according to their diameters: macropores - pores bigger than $0.05 \mathrm{~mm}$ in diameter which are responsible for soil water infiltration; micropores - pores smaller than $0.05 \mathrm{~mm}$ in diameter and are responsible for water storage for plant use; and criptopores - pores smaller than $0.0002 \mathrm{~mm}$ in diameter, where water is retained with a lot of energy, and is unavailable for plant use (RICHARDS, 1965).

Soil porosity is the most important parameter to diagnose the soil compaction, due to the volume ratio of soil available to plants roots, as well as the water and air required (NAWAZ; BOURRIÉ; TROLARD, 2013). The application of animal manure can result in a change in soil structure by modifying the quantity, size and continuity of soil pores (RIBEIRO et al., 2007).

Aeration and water retention in soil influence plant growth as they modify the resistance to roots penetration, consequently resulting in the absorption of water and nutrients (MOSADDEGHI; MAHBOUBI; SAFADOUST, 2009). Daly et al.
(2015) pointed out that water reuse improved the structural conditions of soil due to soil compaction decrease and aeration increase, which are beneficial for rhizosphere development.

However, swine manure application in maize and black oat has several effects on soil. A decrease in the stability of soil aggregates has been observed at 50 and $100 \mathrm{~m}^{3} \mathrm{ha}^{-1}$ doses, in relation to treatments without its application. The soil physical properties and organic carbon content were not modified by 50 and $100 \mathrm{~m}^{3} \mathrm{ha}^{-1}$ treatments. This indicates that the agricultural application of swine manure maintains the soil physical quality (ARRUDA et al., 2010). When soybeans are cultivated, there is a decrease in soil macroporosity, which may cause soil losses and increase in erosion susceptibility (PACHECO et al., 2009).

There is a close relationship between the nutrients absorbed by plants and the soil hydrological regime. However, it is noteworthy that the uptake of water andnutrients by plants is influenced by soil aeration. If the aeration system is deficient, the growth efficiency and root absorption can be severely compromised (COLMER; GREENWAY, 2010).

The application of swine wastewater can reduce pore volume, soil aeration, as well as increase the density of particles. Therefore, its application is recommended on crops with a properly developed roots systems to cause pores reduction (PACHECO et al., 2009).

Furthermore, the application of swine waste water can cause damage to crops, soil physical and chemical properties, as well as the environment. Therefore, studies and proper monitoring are required in evaluating its consequences (VARALLO et al., 2010).

In this context, this study monitored the influence of wastewater application, as cover fertilizer, on maize, based on soil physical properties and sequential crop of black oats as a possible soil decompactor.

\section{MATERIAL AND METHODS}

This study was carried out under field conditions at the Experimental Center of Agricultural Engineering, Western Paraná State University, Campus of Cascavel City, whose geographical location is $24^{\circ} 48^{\prime} \mathrm{S}$ latitude, $53^{\circ} 26^{\prime} \mathrm{W}$ longitude and $760 \mathrm{~m}$ altitude.

The climate is subtropical, mesothermal and super-humid, with $1.800 \mathrm{~mm}$ average annual rainfall, hot summers, with rainfall concentrations without defined dry season and little frequent frosts. The 
annual average temperature is about $2{ }^{\circ} \mathrm{C}$ and $75 \%$ average relative humidity (IAPAR, 2015).

The local soil is classified as dystrophic Oxisol Udic (SOIL SURVEY STAFF, 2014) or red distroferric latosol with a soft relief and clayey soil (EMBRAPA, 2013). Table 1 shows the particle size analysis and chemical characteristics $(0-15 \mathrm{~cm}$ depth).

Table 1. Physical-chemical characteristics of soil before the experiment setting.

\begin{tabular}{|c|c|c|c|}
\hline Parameters $^{1}$ & & Parameters & \\
\hline $\mathrm{P}_{\text {available }}{ }^{2}$ & $7.83 \mathrm{mg} \mathrm{dm}^{-3}$ & Water content $^{3}$ & $0.357 \mathrm{~g} \mathrm{~g}^{-1}$ \\
\hline $\mathrm{C}$ & $25.59 \mathrm{~g} \mathrm{dm}^{-3}$ & Macroporosity ${ }^{3}$ & $0.165 \mathrm{~cm}^{3} \mathrm{~cm}^{-3}$ \\
\hline $\mathrm{Ca}^{++}$ & $6.06 \mathrm{cmol}_{\mathrm{c}} \mathrm{dm}^{-3}$ & Microporosity ${ }^{3}$ & $0.453 \mathrm{~cm}^{3} \mathrm{~cm}^{-3}$ \\
\hline $\mathrm{Mg}^{++}$ & $3.74 \mathrm{cmol}_{\mathrm{c}} \mathrm{dm}^{-3}$ & Total Porosity ${ }^{3}$ & $0.618 \mathrm{~cm}^{3} \mathrm{~cm}^{-3}$ \\
\hline $\mathrm{Al} \ell^{3+}$ & $0.09 \mathrm{cmol}_{\mathrm{c}} \mathrm{dm}^{-3}$ & Bulk density $^{3}$ & $1.12 \mathrm{~g} \mathrm{~cm}^{-3}$ \\
\hline $\mathrm{K}^{+}$ & $0.33 \mathrm{cmol}_{\mathrm{c}} \mathrm{dm}^{-3}$ & Sand $^{4}$ & $125 \mathrm{~g} \mathrm{~kg}^{-1}$ \\
\hline $\mathrm{Cu}$ & $7.60 \mathrm{mg} \mathrm{dm}^{-3}$ & Silt $^{4}$ & $220 \mathrm{~g} \mathrm{~kg}^{-1}$ \\
\hline $\mathrm{Zn}$ & $2.27 \mathrm{mg} \mathrm{dm}^{-3}$ & Clay $^{4}$ & $655 \mathrm{~g} \mathrm{~kg}^{-1}$ \\
\hline $\mathrm{Fe}$ & $23.67 \mathrm{mg} \mathrm{dm}^{-3}$ & $\mathrm{pH}\left(\mathrm{CaCl}_{2}\right)$ & 5.53 \\
\hline $\mathrm{Mn}$ & $155.67 \mathrm{mg} \mathrm{dm}^{-3}$ & CEC & $14.95 \mathrm{cmol}_{\mathrm{c}} \mathrm{dm}^{-3}$ \\
\hline $\mathrm{H}^{+}+\mathrm{Al}^{3+}$ & $4.82 \mathrm{mg} \mathrm{dm}^{-3}$ & Sum of base & $10.13 \mathrm{cmol}_{\mathrm{c}} \mathrm{dm}^{-3}$ \\
\hline
\end{tabular}

${ }^{1}$ According to EMBRAPA (1997); ${ }^{2}$ Mehlich-1, ${ }^{3}$ volumetric ring method (KIEHL, 1979), ${ }^{4}$ Bouyoucos method.

Prior to the present experiment, a no-tillage system had been carried out for 20 years in the cropped area but without the application of swine waste water. This area remained fallow for two years. The data of rainfall, maximum and minimum temperature and relative humidity are shown in Figure 1.

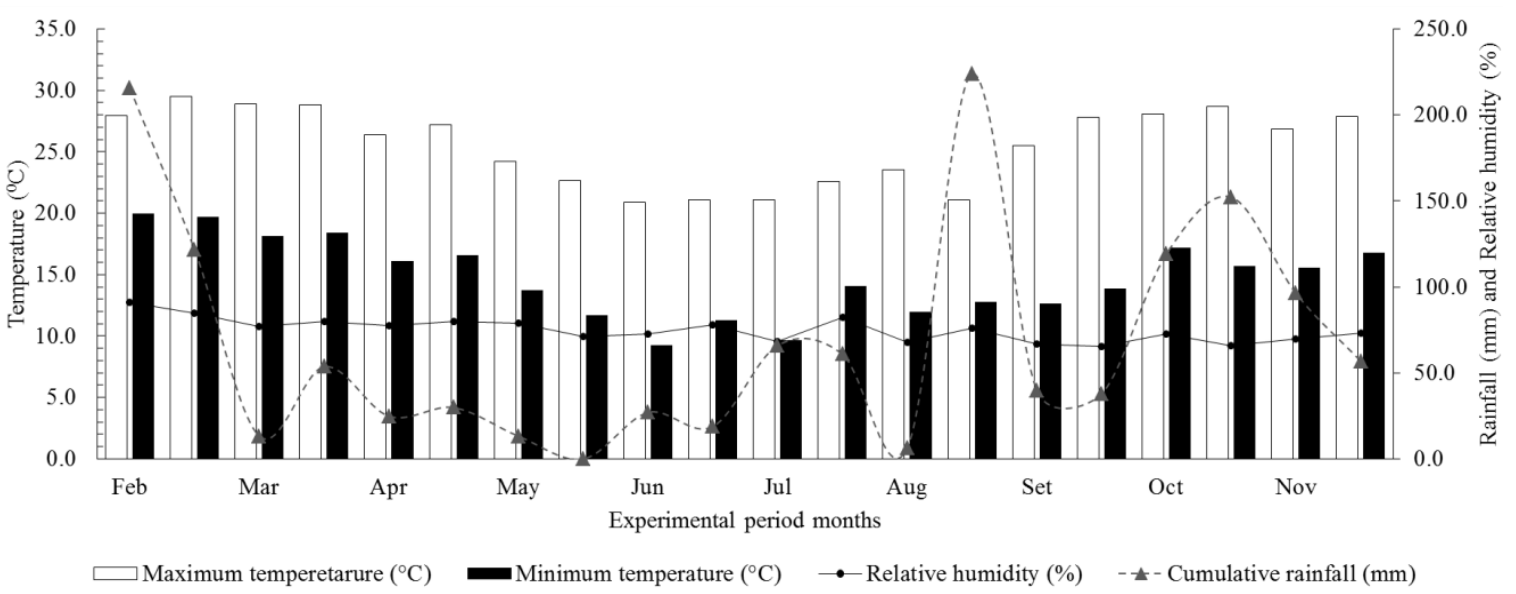

Figure 1. Fortnightly averages of maximum and minimum temperature $\left({ }^{\circ} \mathrm{C}\right)$, cumulative rainfall $(\mathrm{mm})$ and relative humidity (\%) during the experimental period (SIMEPAR, 2012).

Each experimental plot had $3.0 \times 3.3 \mathrm{~m}$ dimensions with $2.0 \mathrm{~m}$ edge among plots in which maize and black oats were grown. The maize crop was sown in March 2011 during the off-season period, using a AS 1596 - Agroeste hybrid with $80 \%$ germination in a laboratory. The row distance was $0.5 \mathrm{~m}$ and five plants were sown per meter using a manual seeder, in order to obtaining a theoretical stand of 80,000 plants ha ${ }^{-1}$.

The black oat crop was sown in July 2011, during the winter, using the IAPAR 61 cultivar, at a distribution rate of $80 \mathrm{~kg} \mathrm{ha}^{-1}$. At each plot, $78 \mathrm{~g}$ of pure seeds were carefully sown for uniform distribution. Thereafter, straw revolving was carried out using a hoe in order to cover the seeds.

The SWW application rates were defined based on the studies of Maggi et al. (2011), who applied swine wastewater at rates of $0,100,200$ and $300 \mathrm{~m}^{3} \mathrm{ha}^{-1}$, for soybean development. They were defined based on the nitrogen concentration obtained from SWW physical-chemical analysis. The application rates are also similar to that used in the study of Meneghetti et al. (2012), who defined SWW application rates based on nitrogen concentration in baby corn crop $\left(0,115,230\right.$ and $\left.345 \mathrm{~m}^{3} \mathrm{ha}^{-1}\right)$.

Besides the standard rates of 0,100 , 200 and $300 \mathrm{~m}^{3} \mathrm{ha}^{-1}$, a treatment was carried out with the equivalent in available $\mathrm{N}$ (nitrate + nitrite + ammonia). Swine wastewater was applied to obtain $60 \mathrm{~kg} \mathrm{ha}^{-1}$, as recommended for cover fertilizer in maize with high yield (FANCELLI; DOURADO NETO, 2008). The SWW concentration was $1,097.6 \mathrm{mg} \mathrm{L}^{-1}$ of the total $\mathrm{N}$, resulting in an application rate of $537 \mathrm{~m}^{3} \mathrm{ha}^{-1}$. 
The swine wastewater was treated in an anaerobic digester, followed by a sedimentation tank (clarifier). Thereafter, aluminum sulfate was used during the flocculation process in a facultative pond from the swine farm. The wastewater was stored in a glass fiber container and $4550 \mathrm{~L}$ was applied. The swine wastewater was collected for chemical characterization $24 \mathrm{~h}$ before and after its application, in order to monitor the applied nutrient. The applied volume was monitored according to the measures obtained in the fiber glass container after 60 days of sowing, when the crop had between six to eight leaves according to the Reference Center for Agriculture and Food of Quebec (CRAAQ, 2003).

Table 2 shows the average amount of macro and micronutrients, electrical conductivity, density and $\mathrm{pH}$ of the swine wastewater used in the experiment. Analyses were conducted on the samples collected before and after conducting the experiment.

Table 2. Total amount of total nitrogen (total N), phosphorus, potassium, sodium, calcium, magnesium, copper, zinc, iron, manganese, electrical conductivity, $\mathrm{pH}$ and density before and after swine wastewater application.

\begin{tabular}{|c|c|c|c|}
\hline Parameters $\left(\mathrm{mg} \mathrm{L}^{-1}\right)$ & Before application & After application & Determination \\
\hline Total nitrogen & $1,097.6$ & $1,068.4$ & Micro-Kjeldahl $^{1}$ \\
\hline Total phosphorus & 122.8 & 128.6 & Visible espectrophtometer \\
\hline Potassium & 525.4 & 534.7 & $\mathrm{AAE}^{2}$ \\
\hline Sodium & 133.6 & 143.0 & AAE \\
\hline Calcium & 57.7 & 60.3 & AAE \\
\hline Magnesium & 33.3 & 31.7 & AAE \\
\hline Copper & 0.81 & 0.90 & AAE \\
\hline Zinc & 4.07 & 3.56 & AAE \\
\hline Iron & 4.08 & 3.49 & $\mathrm{AAE}$ \\
\hline Manganese & 0.29 & 0.33 & AAE \\
\hline Eletrical conductivity $\left(\mu \mathrm{S} \mathrm{cm}^{-1}\right)$ & 1936.7 & 1886.7 & Conductivimeter \\
\hline $\mathrm{pH}$ & 8.2 & 8.3 & pHmeter \\
\hline Density $\left(\mathrm{g} \mathrm{cm}^{-3}\right)$ & 1.003 & 1.004 & Gravimetry \\
\hline
\end{tabular}

${ }^{1}$ Bremner and Keeney $(1965) ;{ }^{2} \mathrm{AAE}=$ atomic absoption espectrophotometer.

Each plot received its respective treatment with four replications, totaling twenty randomly distributed plots.

For physical analysis, two undisturbed soil samples were collected per plot using cylinders with sharp edges per plot at $0-15 \mathrm{~cm}$ depth. The soil samples were placed in aluminum capsules and transported to the laboratory.

The water content was determined using the oven method. Macro, micro, total porosity and soil bulk density were determined using a volumetric ring according to the procedures of Kiehl (1979) and Embrapa (1997), based on the suction table method at 60 wcc until a constant weight was achieved. Thereafter, the samples were placed in an oven at $105 \pm 3^{\circ} \mathrm{C}$ for $24 \mathrm{~h}$.

The experimental design was completely randomized with four replications in stratified sampling. Five SWW rates $(0,100,200,300$ and $537 \mathrm{~m}^{3} \mathrm{ha}^{-1}$ ) were applied as cover fertilizer in maize.

Data normality and the homogeneity of variances were initially evaluated to obtain data variabilities. By using the Minitab ${ }^{\circledR} 14$ software, data transformation was done according to the procedure of Banzatto and Kronka (2013), for parameters that did not show a normal distribution of errors. Thereafter, an analysis of variance (ANOVA) was obtained for each monitored attribute in the soil. The Sisvar $\AA$ software version 5.3 (FERREIRA, 2014) was used to check the statistical significance of the regression models at 0.05 probability.

\section{RESULTS AND DISCUSSION}

The analyses of variance, averages of macro and microporosity, as well as soil total porosity after cultivating maize and black oat crops are shown in Table 3. The models showed no significant difference among treatments for water content. The other soil physical properties showed significance $(\mathrm{P}<0.05)$ for linear, quadratic and cubic models.

The water content was not influenced by the studied treatments of both crops (Figure 2). The organic matter in soil causes water retention (MOLINE et al., 2011). Thus, the organic matter content of the soil is expected to increase with increase in application rate. However, there is no tillage system which conserves straw on soil, keeps high organic matter content and may be seen by the control treatment (MATIAS et al., 2009). Therefore, the increase in water retention provided by organic matter due to application rates is not important. 
Table 3. Analysis of variance, coefficient of variation (CV), standard deviation of water content, macro and microporosity, total porosity and soil bulk after maize crop fertilized with swine wastewater (SWW) and black oats crop in sequence.

\begin{tabular}{|c|c|c|c|c|c|c|c|}
\hline \multicolumn{2}{|c|}{ Variation source } & \multirow{2}{*}{$\begin{array}{c}\text { DF } \\
19\end{array}$} & \multirow{3}{*}{$\begin{array}{l}\text { Water content } \\
\qquad \frac{\left(\mathrm{g} \mathrm{g}^{-1}\right)}{\mathrm{Ns}}\end{array}$} & \multirow{3}{*}{$\begin{array}{c}\text { Macro } \\
\ldots- \\
*\end{array}$} & \multirow{3}{*}{$\begin{array}{c}\begin{array}{c}\text { Micro } \\
-\left(\mathrm{cm}^{3} \mathrm{cn}\right.\end{array} \\
*\end{array}$} & \multirow{3}{*}{$\begin{array}{l}\text { Total porosity } \\
\qquad \begin{array}{c}\text { ) } \\
\text { ) }\end{array}\end{array}$} & \multirow{3}{*}{$\begin{array}{c}\begin{array}{c}\text { Bulk } \\
\left(\mathrm{g} \mathrm{cm}^{-3}\right)\end{array} \\
*\end{array}$} \\
\hline \multirow[t]{2}{*}{ Maize } & SWW rate & & & & & & \\
\hline & Residual error & 17 & & & & & \\
\hline Average & & & 0.312 & 0.1976 & 0.4171 & 0.6151 & 1.341 \\
\hline $\mathrm{CV}(\%)$ & & & 4.1 & 18.09 & 6.1 & 3.14 & 5.74 \\
\hline Standard deviation & & & 0.015 & 0.03 & 0.018 & 0.198 & 0.062 \\
\hline \multirow[t]{2}{*}{ Black oat } & SWW rate & 19 & \multirow{2}{*}{ Ns } & \multirow{2}{*}{$*$} & \multirow{2}{*}{$*$} & \multirow{2}{*}{$*$} & \multirow{2}{*}{$*$} \\
\hline & Residual error & 17 & & & & & \\
\hline Average & & & 0.317 & 0.2354 & 0.3574 & 0.5917 & 1.096 \\
\hline $\mathrm{CV}(\%)$ & & & 4.94 & 11.09 & 9.74 & 5.74 & 4.92 \\
\hline Standard deviation & & & 0.016 & 0.026 & 0.035 & 0.034 & 0.054 \\
\hline
\end{tabular}

ns - no significant by $\mathrm{F}$ test; * - significant at 0.05 by $\mathrm{F}$ test; $\mathrm{DF}=$ degrees of freedom.

In the present study, as the application rates increased, a decrease in macroporosity and soil total porosity was observed, but an increase in microporosity was also observed. This may be attributed to the clogging of macropores which is caused by solids and organic matter from wastewater
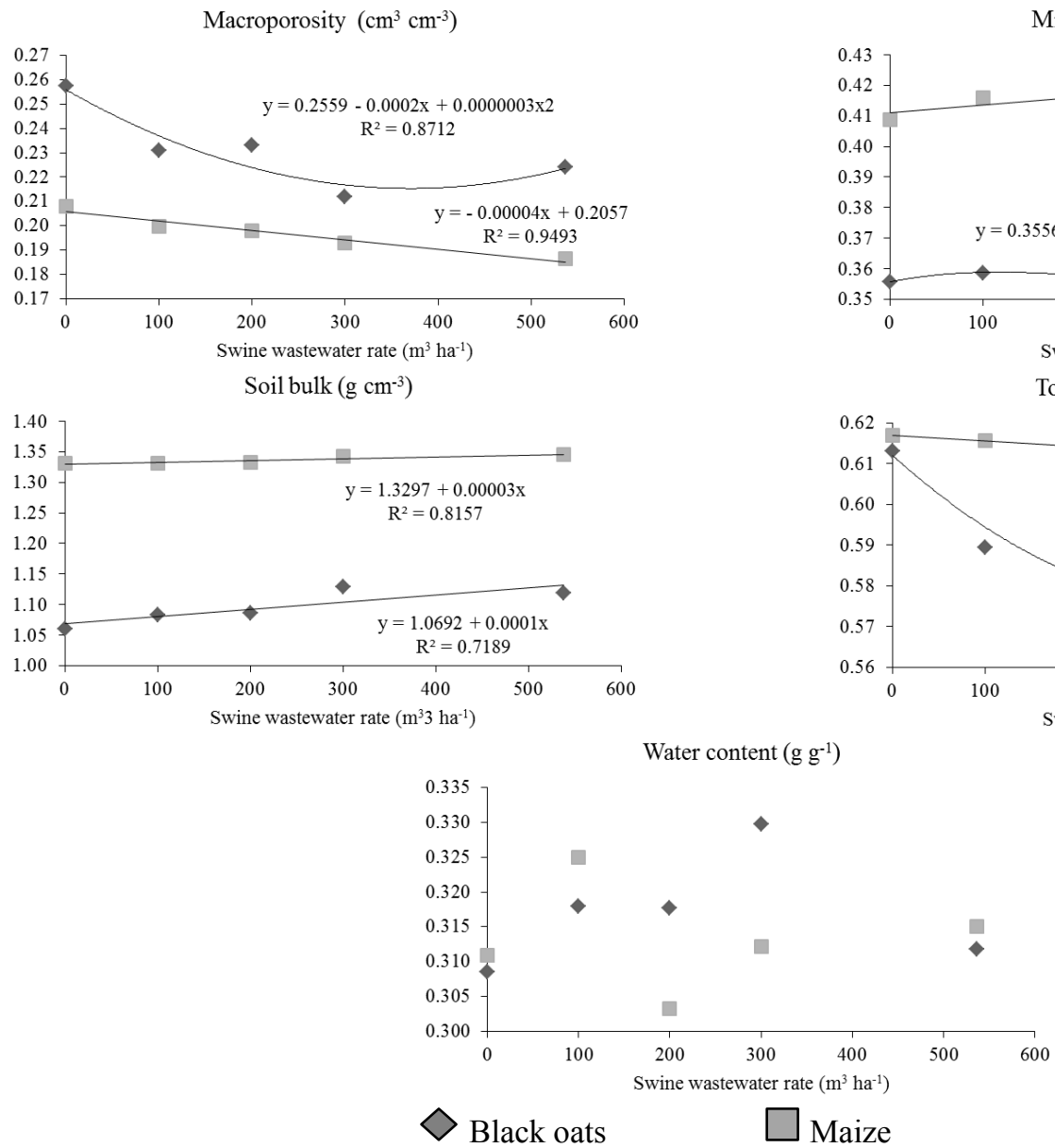

Figure 2. Macro and microporosity, bulk density and soil water content after maize crop fertilized with swine wastewater and black oats crop in sequence.

Rev. Caatinga, Mossoró, v. 30, n. 4, p. 955 - 962, out. - dez., 2017 
Swine wastewater contains large amounts of $\mathrm{Na}^{+}$in soil, mainly when it is higher than the concentrations of $\mathrm{Ca}^{2+}$ and $\mathrm{Mg}^{2+}$. It can cause soil structure degradation by colloidal particle dispersion and subsequent macropores clogging, thereby resulting in lower soil hydraulic conductivity. The magnitude of this effect varies with SWW precipitation and applications in order to promote $\mathrm{Na}^{+}$leaching (ERTHAL et al., 2010).

Macroporosity increased by $23.6 \%$ in the control treatment after fertilization of black oats crop with SWW, 27.7\% in treatment with $200 \mathrm{~m}^{3} \mathrm{ha}^{-1}$ and $20.2 \%$ in treatment with $537 \mathrm{~m}^{3} \mathrm{ha}^{-1}$. There was an average decrease of $14 \%$ in microporosity and $3.6 \%$ in soil total porosity. The decrease in microporosity may have been influenced by the increased macroporosity, which was due to the penetration of rhizosphere cells into the soil.

For maize, the bulk density ranged from 1.268 to 1.345 in the control and $537 \mathrm{~m}^{3} \mathrm{ha}^{-1}$ for treatments, respectively, with no statistical difference among all the treatments (Figure 2). After black oats cropping, there was an average decrease of $17 \%$ of soil bulk. Similar to maize crop, the soil bulk behavior in treatments remained, that is, the control treatment showed lower soil bulk, while the $537 \mathrm{~m}^{3} \mathrm{ha}^{-1}$ treatment was higher. Generally, the decrease in soil bulk can be attributed to the root system growth of black oats, which resulted in an increase in macroporosity.

By comparing soil bulk decrease with macroporosity increase, it was observed that on average, there was a $25 \%$ increase in macroporosity as the soil bulk density decreased by $17 \%$. This was provided by black oats rhizosphere in all treatments.

Arruda et al. (2010) and Hati et al. (2006) applied different swine wastewater rates on soil and found out that, in general, there was an increase in soil bulk density. This may be related to organic matter, which negatively affects soil porosity in treatments with greater organic waste application. Such behavior was repeated in this experiment.

All Oxisols have high macroporosity, ranging from 0.23 to $0.30 \mathrm{~cm}^{3} \mathrm{~cm}^{-3}$ volume in their natural state. This fact provides high capacity of internal drainage in its profile (MONDARDO, 1984). After maize cropping, it was observed that no treatments had such conditions.

Vogeler (2009) recorded soil physical properties in different textures in Taupo and Levin in New Zealand, during a crop period of 12 to 22 years, respectively. The author did not observe any significant changes in soil structure when wastewater from the treatment station of domestic sewage was applied. However, some decrease in macroporosity was observed due to the stress of sequence applications.

After black oats cropping, appropriate values were obtained for macroporosity during treatments until $200 \mathrm{~m}^{3} \mathrm{ha}^{-1}$ rates were obtained. This indicates that other treatments can decrease macroporosity to reduce internal drainage in the soil profile. This did not match the increased macroporosity by the black oats root system and decreased the soil quality for this parameter.

Nunes, Bonfim-Silva and Silva (2016) recorded that oxisol is deficient in aeration because it is clayey, and has a soil bulk density close to $1.30 \mathrm{mg} \mathrm{m}^{-3}$. For the same soil class, Klein (2006) noted that the limiting bulk density was $1.33 \mathrm{mg} \mathrm{m}^{-3}$, based on the best optimum limiting water range. Reinert et al. (2008) proposed a critical soil bulk density for some textures: 1.30 to $1.40 \mathrm{mg} \mathrm{m}^{-3}$ for clay soils, 1.40 to $1.50 \mathrm{mg} \mathrm{m}^{-3}$ for franc - clay soils and 1.70 to $1.80 \mathrm{mg} \mathrm{m}^{-3}$ for sandy loam soils.

According to Reinert et al. (2008), compaction is a serious problem for soil quality and sustainable agricultural development. This is because it modifies the flow of water and air in soil, and reduces crop yield. A method of solving this problem is by species manegment with a deep and vigorous root system, such as velvet beans, crude, pigeon pea, jack beans and black oats, as evaluated in this experiment.

In this context, it was observed that maize crop experienced some aeration deficiency in the soil of all treatments with SWW (soil bulk density greater than $1.3 \mathrm{mg} \mathrm{m}^{-3}$ ), and treatments with 300 and $537 \mathrm{~m}^{3} \mathrm{ha}^{-1}$ showed higher bulk density than the limiting one for root growth $\left(1.33 \mathrm{mg} \mathrm{m}^{-3}\right)$ as confirmed by Klein (2006).

After the cultivation of black oats, there was a reduction in soil bulk density below the critical levels of aeration deficiency and root growth. Thus, the cultivation of black oats crop in areas with bulk density near $1.3 \mathrm{mg} \mathrm{m}^{-3}$ contributed to the increase in soil physical quality and reduced compaction in the evaluated $0-15 \mathrm{~cm}$ layer. An increase in macroporosity was observed, which was caused by applications until $200 \mathrm{~m}^{3} \mathrm{ha}^{-1}$ rates, in order to reduce compaction and reconstruct the soil structure. Microporosity increased due to higher application rate in maize and decreased after the cultivation of black oats.

Higher application resulted in an increase in soil bulk density. After the cultivation of black oats, there was a decrease below the critical levels of aeration deficiency and root growth. This indicates that black oat contributed to the increase in soil physical quality and reduced compaction from 0 to $15 \mathrm{~cm}$ surface layer.

\section{CONCLUSION}

This study was carried out under soil and climatic conditions. Swine wastewater application, as cover fertilizer in maize and black oats in sequence, showed the following effects on soil physical properties: it did not influence water content; it 
reduced macroporosity and soil total porosity at higher application rate on maize and as a result, there was some deficiency in soil aeration for the studied crop. However, after the cultivation of black oats, there was an increase in macroporosity at adequate levels for root system development until $200 \mathrm{~m}^{3} \mathrm{ha}^{-1}$ rates were obtained.

Swine wastewater application rates of up to $200 \mathrm{~m}^{3} \mathrm{ha}^{-1}$ caused deficiency in aeration for maize crop. This may not be reversible only with the cultivation of black oats in sequence. Therefore, with continuous application, they can cause degradation in soil physical quality, which can decrease the yield of most annual crops.

\section{ACKNOWLEDGEMENT}

The authors would like to thanks to CAPES for the financial support, to COOPAVEL for the biofertylizer and to IAPAR for black oats seeds donation.

\section{REFERENCES}

ARRUDA, C. A. O. et al. Aplicação de dejeto suíno e estrutura de um Latossolo Vermelho sob semeadura direta. Ciência e Agrotecnologia, Lavras, v. 34, n. 4, p. 804-809, 2010.

BANZATTO, D. A.; KRONKA, S. N. Experimentação agrícola. 4. ed. Jaboticabal, SP: Funep, 2013. 237 p.

BREMNER, J. M.; KEENEY, D. R. Steam distillation methods for determination of ammonium, nitrate and nitrite. Analytica Chimica Acta, Louisville, v. 32, n. 1, p. 485-495, 1965.

\section{CENTRE DE RÉFÉRENCE EN AGRICULTURE ET AGROALIMENTAIRE DU} QUÉBEC - CRAAQ. Guide de référence en fertilisation, 1. ed. Québec: CRAAQ, Canada, 2003, $473 \mathrm{p}$.

COLMER, T. D.; GREENWAY, H. Ion transport in seminal and adventitious roots of cereals during $\mathrm{O}_{2}$ deficiency. Journal of Experimental Botany, Lancaster, v. 1, n. 62, p. 1-19, 2010.

DALY, K. R. et al. Assessing the influence of the rhizosphere on soil hydraulic properties using X-ray computed tomography and numerical modelling. Journal of Experimental Botany, Lancaster, v. 66, n. 8 , p. $2305-2314,2015$.

EMPRESA BRASILEIRA DE PESQUISA AGROPECUÁRIA - EMBRAPA. Manual de métodos de análise do solo. 2. ed. Rio de Janeiro,
RJ: CNPS, Ministério da Agricultura e do Abastecimento, 1997, 212 p.

EMPRESA BRASILEIRA DE PESQUISA AGROPECUÁRIA - EMBRAPA. Sistema brasileiro de classificação de solos. 3. ed. Brasília, DF: Embrapa, 2013. 353 p.

ERTHAL, V. J. T. et al. Alterações físicas e químicas de um Argissolo pela aplicação de água residuária de bovinocultura. Agriambi, Campina Grande, v. 14, n. 5, p. 467-477, 2010.

FANCELLI, A. L.; DOURADO NETO, D. Produção de milho. 2. ed. Guaíba, RS: Editora Agropecuária, 2008, 360 p.

FERREIRA, D. F. Sisvar: a Guide for its Bootstrap procedures in multiple comparisons. Ciência e Agrotecnologia, Lavras, v. 38, n. 2, p. 109-112, 2014.

HATI, K. M. et al. Effect of inorganic fertilizer and farmyard manure on soil physical properties, root distribution, and water-use efficiency of soybean in Vertisols of central India. Bioresource Technology, Oxford, v. 97, n. 16, p. 2182-2188, 2006.

INSTITUTO AGRONÔMICO DO PARANÁ - IAPAR. Cartas Climáticas do Estado do Paraná - Cascavel. Londrina, PR: IAPAR, 2015, $3 \mathrm{p}$.

KIEHL, E. J. L. Manual de edafologia. 1. ed. São Paulo, SP: Ed. Agronômica Ceres. 1979, 263 p.

KLEIN, V. A. Densidade relativa - um indicador da qualidade física de um Latossolo Vermelho. Revista de Ciências Agroveterinárias, Lages. v. 5, n. 1, p. 26-32, 2006.

MAGGI, C. E. et al. Lixiviação de nutrientes em solo cultivado com aplicação de água residuária de suinocultura. Revista Brasileira de Engenharia Agrícola e Ambiental, Campina Grande, v. 15, n. 2, p. 170-177, 2011.

MATIAS, S. S. R. et al. Atributos físicos de um Latossolo Vermelho submetido a diferentes usos. Revista Ciência Agronômica, Fortaleza, v. 40, n. 3, p. 331-338, 2009.

MENEGHETTI, A. M. et al. Mineral composition and growth of babycorn under swine wastewater combined with chemical fertilization. Revista Brasileira de Engenharia Agrícola e Ambiental, Campina Grande, v. 16, n. 11, p. 1198-1205, 2012.

MOLINE, E. F. V. et al. Redução das perdas de água e solo em função do volume de palhada na superfície 
de um solo em Rondônia. Global Science and Technology, Rio Verde, v. 4, n. 2, p. 91-97, 2011.

MONDARDO, A. Manejo e conservação do solo. In: TORRADO, P. V., ALOISI. R. R. (Eds.). Plantio direto no Brasil. Campinas: Fundação Cargil, 1984, v. 1 , cap. 3 , p. 53-78.

MOSADDEGHI, M. R.; MAHBOUBI, A. A.; SAFADOUST, A. Short-term effects of tillage and manure on some soil physical properties and maize root growth in a sandy loam soil in western Iran. Soil and Tillage Research, Amsterdam, v. 104, n. 1, p. 173-179, 2009.

NAWAZ, M. F.; BOURRIÉ, G.; TROLARD, F. Soil compaction impact and modelling. A review. Agronomy for Sustainable Development, Paris, v. 33, n. 2, p. 291-309, 2013.

NUNES, J. A. S.; BONFIM-SILVA, E. M.; SILVA, T. J. A. Bulk density and water tensions in the soil on corn root production. Revista Brasileira de Engenharia Agrícola e Ambiental, Campina Grande, v. 20, n. 4, p. 357-363, 2016.

PACHECO, F. P. et al. Monitoramento das propriedades físicas do solo irrigado com água residuária no cultivo da soja. In: LEO, N. D.; MONTICO, S.; NARDÓN, G. (Eds.). Avances em Ingeniería Rural 2007-2009. Rosario, SF: UNR Editora, 2009, v. 1, n. 1, p. 796-803.

REINERT, D. R. et al. Limites críticos de densidade do solo para o crescimento de raízes de plantas de cobertura em argissolo vermelho. Revista Brasileira de Ciência do Solo, Viçosa, v. 32, n. 5, p. 1805-1816, 2008.

REIS, L. B.; FADIGAS, E. A. A.; CARVALHO, C. E. Energia, recursos naturais e a prática do desenvolvimento sustentável. 1. ed. Barueri, SP: Manole, 2005. 41 p.

RIBEIRO, K. D. et al. Propriedades físicas do solo, influenciadas pela distribuição de poros, de seis classes de solos da região de Lavras-MG. Ciência e Agrotecnologia, Lavras, v. 31, n. 4, p. 1167-1175, 2007.

RICHARDS, L. A. Physical conditions of water in soil. In: BLACK, C. A. et al. (Eds.). Methods of soil analysis: physical and mineralogical properties, including statistics of measurements and sampling. Madison: American Society of Agronomy, 1965. p. 128-152.

RIENZI, E. A. et al. Autoregressive state spatial modeling of soil bulk density and organic carbon in fields under different tillage system. Soil and Tillage
Research, Florence, v. 159, n. 1, p. 56-66, 2016.

SILVA, T. O. et al. Plantas de cobertura submetidas a diferentes fontes de fósforo em solos distintos. Semina: Ciências Agrárias, Londrina, v. 32, n. 4, p. 1315-1326, 2011.

SISTEMA METEOROLÓGICO DO PARANÁ - SIMEPAR. Dados climáticos de Cascavel - PR. 2012. Disponível em: <http:// www.simepar.br>. Acesso em: 17 abr. 2017.

SOIL SURVEY STAFF. Keys to Soil Taxonomy. $12^{\text {th }}$. ed. Washington, DC: USDA-Natural Resources Conservation Service, 2014, 372 p.

VARALLO, A. C. T. et al. Alterações nos atributos de um Latossolo Vermelho-amarelo irrigado com água de reuso. Revista Brasileira de Engenharia Agrícola e Ambiental, Campina Grande, v. 14, n. 4, p. 372-377, 2010.

VOGELER, I. Effect of long-term wastewater application on physical soil properties. Water, Air and Soil Pollut. Guelph, v. 196, n. 1, p. 385-392, 2009.

ZAMANI, J. et al. Opposite effects of two organic wastes on the physical quality of an agricultural soil. Archives of Agronomy and Soil Science, Bernburg, v. 62, n. 3, p. 413-427, 2016. 